\title{
Manevi İçerikli Grup Rehberliğinin Özel Gereksinimli Çocuk Sahibi Annelerin Dini Başa Çıkma Düzeylerine Etkisinin İncelenmesi*
}

\section{Sema Karagöz**}

Öz

Bu araștırmanın amacı özel gereksinimli çocuk sahibi annelere yönelik uygulanan manevi içerikli grup rehberliği programının olumlu dini başa çıkma ve olumsuz dini başa çıkma düzeyleri üzerindeki etkisini incelemektir. Araştırmada 66 özel gereksinimli çocuk sahibi anneye ulaşılmış ve gerçekleştirilen taramalar neticesinde dahil etme kriterlerine göre 24 anne deney ve kontrol gruplarına atanmıștır. Gönüllü onam formunun alınmasıyla 12 kişilik kontrol grubuna herhangi bir işlem uygulanmazken 12 kişilik deney grubuna manevi içerikli grup rehberliği programı uygulanmıştır. Manevi içerikli grup rehberliği programı her hafta 90 dakikadan oluşan oturumlarla 10 hafta boyunca devam etmiştir. Katılımcllara program öncesinde ve sonrasında Sosyo-Demografik Bilgi Formu ve Dini Başa Çıkma Ölçeği uygulanmıştır. Veriler SPSS istatistik programı aracılığıyla analiz edilmiş ve nonparametrik testler kapsamında yer alan Mann-Whitney U Testi ve Wilcoxon İşaretli Sıralar Testi kullanılmıştır. Araştırmada elde edilen bulgulara göre deney grubu katılımcılarının olumlu dini başa çıkma düzeylerinde anlamlı düzeyde artma olmuştur. Olumsuz dini başa çıma düzeylerinde de uygulama sonrasında anlamlı düzeyde azalma meydana gelmiştir. Ayrıca deney grubu ve kontrol grubundaki katılımcıların uygulama öncesindeki olumlu ve olumsuz dini başa çıkma ön-test puanlarında anlamlı bir farklılı bulunmuyorken uygulama sonrasında anlamlı farklılık meydana geldiği tespit edilmiştir.

Anahtar Kelimeler: Maneviyat, Grup Rehberliği, Özel Gereksinimli Çocuk, Dini Başa Çıkma, Anlam.

\section{Analysis of the Effect of Group Guidance With Spiritual Content on the Religious Coping Levels of Mothers of Children with Special Needs}

\begin{abstract}
The aim of this study is to examine the effect of a group guidance program with spiritual content applied to mothers of children with special needs on their positive religious coping and negative religious coping levels. In the study, 66 mothers of children with special needs were reached and, after screening, 24 mothers were assigned to experimental and control groups according to inclusion criteria. After obtaining informed consent forms, no action was taken with the control group of 12 participants, while the group guidance program with a spiritual content was held with

Bu makale, "Manevi İçerikli Grup Rehberliğinin Özel Gereksinimli Çocuk Sahibi Annelerin Dini Başa Çılkma, Psikolojik İyi Oluş ve Kaygı Düzeylerine Etkisinin İncelenmesi” başlıklı doktora tezi temel alınarak hazırlanmıştır.

** Doktora Öğrencisi, Marmara Üniversitesi Sosyal Bilimler Enstitüsü, sema.karagoz@yahoo.com.tr ORCID ID 0000-0002-6731-3883
\end{abstract}


the experimental group of other 12 participants. The spiritual group guidance program continued for 10 weeks, with sessions of 90 minutes each week. The SocioDemographic Information Form and Religious Coping Scale were applied to the participants before and after the program. The data were analysed through the SPSS statistical program, and the Mann-Whitney U Test and the Wilcoxon Signed Ranks Test, which are non-parametric tests, were used. According to the findings obtained in the study, there was a significant increase in the positive religious coping levels of the experimental group participants. There was also a significant decrease in negative religious coping levels after the program. Additionally, while there was no significant difference in the positive and negative religious coping pre-test scores of the participants in the experimental group and the control group before the program, a significant difference was observed after the program.

Keywords: Spirituality, Group Guidance, Special Needs Children, Religious Coping, Meaning.

\section{Giriş}

Aile sistemine bir çocuğun dahil olmasıyla aile yaşam döngüsünde yeni bir basamağa geçiş söz konusu olmaktadır. Bu yeni ferdin sisteme katılımıyla annebabalar yeni roller üstlenmekteler ve yeni koşullara uyum sağlayabilmek için çaba göstermektedirler. ${ }^{1}$ Normal özellikler gösteren bir çocuğun aileye katılımı dahi pek çok yenilik ve değişiklik anlamına gelirken özel gereksinimli çocuğun aileye dahil olmasıyla ailevi işleyişte ve aile fertlerinin rollerinde çok daha belirgin ve önemli değişimler meydana gelmektedir. ${ }^{2}$

Çocuğa özel gereksinimli tanısının konulmasıyla, ilk aşamada aile fertlerinin psikolojik uyumlarının seyrini incelemek önem taşımaktadır. Tanının öğrenilmesiyle anne-babalar yoğun bir keder ve kayıp hissi tecrübe etmektedirler. ${ }^{3}$ Şüphesiz, çocuk sahibi olmayı planladıkları ilk andan itibaren anne-babaların hayalleri, beklentileri, umut ve hazırlıkları sağlıklı bir bebek üzerinedir. ${ }^{4} \mathrm{Bu}$ beklenmeyen tanının alınmasıyla ebeveynler hayallerini, planlamalarını, umutlarını ve hayata dair kontrol hissini kaybetmekte; bu kayıp hissi de yoğun bir kedere neden olmaktadır. ${ }^{5}$

Şu ana dek yapılan gözlemler ve araştırmalar tanının öğrenilmesiyle annebabaların genellikle şok, inkâr, suçluluk, üzüntü, kızgınlık, hayal kırıklığı, kaçınma,

1 Havva Kaçan Softa, "Engelli Çocuğa Sahip Ebeveynlerin Depresyon Düzeylerinin İncelenmesi”, Kastamonu Ĕ̈itim Dergisi 21/2 (2013), 590.

2 Tali Heiman - Ornit Berger, "Parents of Children with Asperger Syndrome or with Learning Disabilities: Family Environment and Social Support", Research in Developmental Disabilities 29/4 (2007), 289; Sevgi Küçüker, "Erken Eğitimin Gelișimsel Geriliği Olan Çocukların AnneBabalarının Stres ve Depresyon Düzeyleri Üzerindeki Etkisinin İncelenmesi”, Özel Eğitim Dergisi $1 / 3$ (2001), 2.

3 Tom E. C. Smith vd., Families and Children with Special Needs (New Jersey: Pearson, 2006), 57.

$4 \quad$ Mehibe Akandere vd., "Zihinsel ve Fiziksel Engelli Çocuğa Sahip Anne ve Babaların Yaşam Doyumu ve Umutsuzluk Düzeylerinin İncelenmesi", Selçuk Üniversitesi Sosyal Bilimler Enstitüsü Dergisi 22 (2009), 24.

5 Julia Shank Dawson, A Spiritual Resource of Hope and Healing for Parents of Seriously Ill Children (New Jersey: Drew University, 2008), 28. 
benlik saygısında azalma gibi tepkilerde bulunduklarını göstermektedir. ${ }^{6}$ Bu gözlem ve deneyimler göz önünde bulundurularak ailelerin tepkilerini açıklamaya çalışan modeller oluşturulmaya çalışılmıştır. Bu modellerden en yaygın kabul göreni Kubler Ross tarafından oluşturulan beş basamaklı aşama modelidir. ${ }^{7}$ Aşama modeline göre; şok/inkâr, öfke, pazarlık, depresyon ve kabul olmak üzere beş basamak bulunmaktadır. $^{8}$ Şok aşamasında, tanının ilk kez öğrenilmesiyle anne-babalar tepki verememekte, öylece kalakalmakta ve kendilerini dışarıdan izlemektedirler. ${ }^{9}$ Daha sonra, bu şoktan yavaş yavaş sıyrılmaya başlamaktalar, tanıya ilişkin şüpheler kendini göstermekte ve çocuğun iyileşeceğine dair bir umutla veya tanıda yanlışlık olduğu inancıyla doktor doktor gezerek inkâr tepkisi göstermektedirler. ${ }^{10}$ Öfke aşamasında ise 'Neden ben?' sorgulamaları ağırlık kazanmaktadır. ${ }^{11}$ Çevredeki normal gelişim özelliklerine sahip çocuklara ve ailelerine bakılarak 'Onların neden böyle bir çocuğu yok?' denilebilir. ${ }^{12} \mathrm{Bu}$ öfke uzmanlara, ailenin diğer fertlerine yöneltilebileceği gibi ${ }^{13}$ 'Allah'ım dünyada bu kadar insan yaşarken neden beni seçtin?' gibi cümlelerle Yaratıcı'ya da aktarılabilir. ${ }^{14}$ Pazarlık aşamasında ise doktorlar, uzmanlar ya da Yaratıcı ile pazarlık etme davranışı görülmektedir ${ }^{15}$; 'Bu tedavinin işe yaramasına izin verirsen; daha iyi bir insan olacağıma dair söz veririm.' gibi cümleler dile getirilmektedir. ${ }^{16}$ Anne-babalar, depresyon aşamasında artık daha gerçekçi değerlendirmeler yapmaya başlamakta ${ }^{17}$; hayallerindeki çocuğu, planlamalarını, umutlarını değiştirmeleri gerektiğini fark etmektedirler. ${ }^{18}$ Kabul aşamasıyla da

$6 \quad$ William L. Heward, Exceptional Children an Introduction to Special Education (New Jersey: Pearson Education, 2009), 93; Akandere, "Zihinsel ve Fiziksel Engelli Çocuğa Sahip Anne ve Babaların Yaşam", 22. Smith vd., Families and Children with Special Needs, 58.

$8 \quad$ Atilla Cavkaytar vd., Özel Eğitimde Aile Eğitimi ve Rehberliği (Ankara: Vize Basın Yayın, 2013), 29; Bogdanna Andreyko, "The Emotional State of Parents in the Structure of the Stages of the Experience of Having a Child with Developmental Disabilities", Journal of Education Culture and Society 2 (2016), 152; Suzan K. Dzubay, Parental Grief, Coping Strategies and Challenges When a Child Has Autism Spectrum Disorder (Wisconsin: The Graduate School University of WisconsinStout, Family Studies and Human Development, Yüksek Lisans Tezi, 2011), 28; Isack Kandel Joav Merrick, "The Birth of a Child with Disability", The Scientific World Journal 3 (2003), 743. Nancy Hunt - Kathleen Marshall, Exceptional Children and Youth (Boston: Houghton Mifflin Company, 1999), 70. Andreyko, The Emotional State of Parents, 152.

Smith vd., Families and Children with Special Needs, 58.

Hunt - Marshall, Exceptional Children and Youth, 71.

Dzubay, Parental Grief, 29.

Sema Karagöz, Otistik Çocukların Anne Babalarında Anlamlandırma ve Dini Başa Çıkma (İstanbul: Marmara Üniversitesi, Sosyal Bilimler Enstitüsü, Yüksek Lisans Tezi, 2010), 64.

Cavkaytar vd., Özel Ĕ̆itimde Aile Eğitimi ve Rehberliği, 30.

Dzubay, Parental Grief, 29.

Smith vd., Families and Children with Special Needs, 58.

Cavkaytar vd., Özel Eğitimde Aile Eğitimi ve Rehberliği, 31. 
ebeveynler yaşamlarını daha iyi yönetebilir düzeye gelmekte; ${ }^{19}$ çocuğun özelliklerine uygun beklenti ve planlamalar oluşturmaya başlamaktadırlar. ${ }^{20}$

Anne-babaların bu tecrübeleri kimi zaman döngüsel bir biçimde tekrarlayarak kendini gösterebilir; özel gereksinimli çocuğa uyum sağlamak yaşam boyu devamlılık gösteren bir durumdur. ${ }^{21}$ Nitekim, doğumla başlayan farklılık ve güçlükler, okula başlama yaşı geldiğinde ya da ergenlik krizleriyle yenilenerek ortaya çıkmaktadır. Bu da anne-babaların rol ve sorumluluk alanlarında sürekli yeniliği ve değişimi sağlamalarını gerektirmektedir. ${ }^{22} \mathrm{Bu}$ süreçte her anne-babanın deneyimi çok özel olmakla birlikte ortaklıklardan yola çıkarak sınıflandırılan ailelerin tecrübe ettikleri sorun alanları kısaca şu şekildedir:

Duygusal ve Fiziksel Sorunlar: Tanının öğrenilmesiyle beraber deneyimlenen şok, inkâr, üzüntü, öfke, umudunu yitirme gibi duyguların yanında anne-babalar gelecekte ne olacağını ve neler yapmaları gerektiğini bilmemenin endişesini de yaşamaktadırlar. ${ }^{23}$ Anne-babaların yüksek düzey stresleri, uyku sorunlarına, sindirim sistemi bozukluklarına, zaman zaman kendine ve çevreye zarar veren davranışlara neden olabilmektedir. ${ }^{24}$

Sosyal İlişkilerde Yaşanan Sorunlar: Özel gereksinimli çocukla yaşam annebabaların sosyal etkinliklere katılımının da sınırlanması anlamını taşımaktadır. Çocuğa vakit ayırabilmek için anne-babalar diğer insanlarla ilişkilerini azaltmakta ya da faaliyetlere katılamamaktadırlar. Ayrıca çocuğun durumu dışarıdan anlaşılamadığında veya çocuk tuhaf davranışlar sergilediğinde etraftaki insanlar eleştiri yönelttikleri için ebeveynler dışarı çıkmak istememektedirler. ${ }^{25}$

Eğitim ve Tedavi ile İlgili Yaşanılan Sorunlar: Anne-baba bir yandan özel gereksinimli çocuğa içsel dünyasında uyum sağlamaya çalışırken bir yandan da ona nasıl bakım vereceğini öğrenmek ve bilgi sahibi olmak için mücadele etmektedir. ${ }^{26}$

Johannah E. M. Betman, Parental Grief When a Child Is Diagnosed with a Life-Threatening ChronicIllness: The Impact of Gender, Perceptions and Coping Strategies (New Zealand: University of Canterbury, Master of Arts in Psychology, Yüksek Lisans Tezi, 2006), 18. Hunt - Marshall, Exceptional Children and Youth, 71. Marika Veisson, "Depression Symptoms and Emotional States in Parents of Disabled and NonDisabled Children", Social Behavior and Personality: An International Journal 27/1 (1999), 95. Michelle M. Lindholm, Stress, Coping and Quality of Life in Families Raising Children with Autism (California: School of Professional Psychology Allinant International University, Doktora Tezi, 2007), 9. Cemile Ö. Sarıhan, Engelli Çocuğa Sahip Olan ve Olmayan Annelerin Aile İșlevlerini Algılamaları ile Yalnızlık Düzeylerinin İncelenmesi (Ankara: Ankara Üniversitesi, Fen Bilimleri Enstitüsü, Yüksek Lisans Tezi, 2007), 19. 
Günlük bakım vermede yaşanılan güçlüklerin yanında uygun eğitim ve tedavi merkezlerinin seçimi de ebeveynler için zorlayıcı olmaktadır. ${ }^{27}$

Maddi Sorunlar: Özel gereksinimli çocukların günlük bakım, tedavi, eğitim gibi alanlardaki ihtiyaçları normal bir çocuğun masraflarına nazaran çok daha fazladır. Bu da ek bir bütçe ayırmayı zorunlu kılmaktadır. Ebeveynler terapi, eğitim, oyuncak, temel bakım gibi giderlerde zorlandıklarını dile getirmektedirler. ${ }^{28}$

Anne-babalar, tedavi ve eğitim sürecinde yaşanan güçlükler, aile içi uyum problemleri, bakım yükü ya da gelecekte neyin beklediğine ilişkin bilinmezlik gibi hususlardan ötürü stres yaşamaktadırlar. ${ }^{29}$ Aileler, bu stres verici faktörlerle başa çıkmaya çalışırken eğitim ve tedavi hizmetlerinden destek almakta, yakın akrabalardan yardım istemekte, benzer diğer ailelerle dayanışmakta, çeşitli etkinliklere katılmakta ya da dini ve manevi kaynaklarına başvurmaktadırlar. ${ }^{30}$

Dini ve manevi kaynaklar, anne babalar için hem özel gereksinimli çocuğa sahip olmaya anlam vermede hem de hayat boyu devam eden mücadele sürecinde destek işlevi görmektedir. ${ }^{31}$ Ebeveynler anlam yükleme aşamasında bilişsel şemalarıyla ilişkili olarak kimi zaman iyimser dini değerlendirmelerin ve Tanrı'yla işbirliğinin hakim olduğu olumlu dini başa çıkma tutumu sergilerler kimi zaman da Tanrı'yla zayıf bir ilişkinin ve kötücül düşüncelerin ağırlıkta olduğu olumsuz dini başa çıkmaya başvururlar. ${ }^{32}$ Birincisinde, özel gereksinimli çocuğu Tanrı'nın bir hediyesi, planlaması, aile üyelerinin yakınlaşması, manevi tecrübelerin artması için olumlu bir destek kaynağı olarak değerlendirmektedirler. İkincisinde ise Tanrı tarafından cezalandırıldıklarını ve Tanrı'nın sadece özel anne-babalara sağlıklı, güzel, akıllı çocuklar gönderdiğini düşünmektedirler. Şüphesiz olumsuz dini başa çıkma eğilimi anne-babaların stres düzeyini artırmakta ve yaşamdaki iyilik hâlleri üzerinde olumsuz etkide bulunmaktadır. ${ }^{33}$

Özel gereksinimli çocuğu olan ebeveynler, karşılaştıkları bu beklenmedik ve zorlayıcı durumla başa çıkmaya çalışırken anlam arayışına girmektedirler. Bir anlam oluşturamamak ya da oluşturulan anlamın içeriği, anne-babalar için kimi zaman ızdırap verici olabilmekte ve psikolojik sağlığı olumsuz yönde etkilemektedir.

Ahmet Güneş, Otizm ve Otistik Çocukların Eğitimi (İzmir: İlya İzmir Yayınevi Matbaası, 2005), 53. Nilgün Bıçak, Otizmli Çocukların Annelerinin Yaşadıklarının Belirlenmesi (Bolu: Abant İzzet Baysal Üniversitesi, Sosyal Bilimler Enstitüsü, Yüksek Lisans Tezi, 2009), 26.

Anja Taanila vd., "Coping of Parents with Physically and/or Intellectually Disabled Children", Child, Care, Health \& Development 28/1 (2002), 74.

David E. Gray, "Coping over Time: The Parents of Children with Autism", Journal of Intellectual Disability Research 50/12 (2006), 972.

Nalini Tarakeshwar - Kenneth I. Pargament, "Religious Coping in Families of Children with Autism", Focus on Autism and Other Developmental Disabilities 16/4 (2001), 248-249.

Jeffrey P. Bjorck - John W. Thurman, "Negative Life Events, Patterns of Positive and Negative Religious Coping and Psychological Functioning", Journal for the Scientific Study of Religion 46/2 (2007), 160.

Tarakeshwar - Pargament, “Religious Coping in Families of Children with Autism”, 248-249. 
Ebeveynler, iyilik hâllerini ve iç barışıklıklarını destekleyici bir anlam oluşturmada kimi zaman güçlük yaşayabilirler. Dolayısıyla, özel gereksinimli çocuk sahibi annebabalar için anlam kaynaklarını keşfedebilecekleri, manevi iyilik hallerini destekleyebilecekleri, manevi sıkıntılarını ifade edebilecekleri ve manevi çatışmalarını azaltma imkânı yakalayabilecekleri danışmanlık ve rehberlik uygulamaları önem taşımaktadır. Ayrıca bu uygulamalarda anne-babaların yalnız olmadıklarına, diğer insanlarla ilişki kurabilmelerine, kendilerini ifade edebilmelerine, günlük yaşamdaki sorunlarla daha etkili baş edebilmelerine de yer verilebilir. Böylece bütüncül bir perspektifle iyilik hallerine destek olunması sağlanabilir.

Manevi yönelimli grupla danışmanlık ve rehberlik uygulamalarına ilişkin önemin son zamanlarda fark edildiğine ve yavaş yavaş artış yaşandığına şahit olmaktayız. ${ }^{34}$ Özellikle yurt dışında bu bağlamda yapılan çalışmalara rastlamaktayız. Rosmarin ve diğerleri ${ }^{35}$ hastalarla grupla manevi yönelimli bilişsel davranışçı terapi programı gerçekleştirmişlerdir. $\mathrm{Bu}$ terapi programının içeriğinde psikiyatrik belirtilerle maneviyatın ilişkisine dair psiko-eğitim verme, manevi inançların birleşimiyle yeniden yapılandırma ve manevi etkinlikler yer almıștır. Christmas ve Horn $^{36}$ da maneviyatın entegre edildiği psiko-eğitim ağırlıklı bir model oluşturmuştur. Özellikle kanser tanısı almış hastalarla manevi yönelimli grup çalışmalarının varlığı dikkat çekicidir. Cole ve Pargament ${ }^{37}$ kanser tanılı hastalarla gerçekleștirdikleri 'Kanser Sonrası ve Süresince Yaşamı Yeniden Yaratmak' başlıklı araştırmalarında anlam konusunu işlemişlerdir. Benzer şekilde Breitbart ve diğerleri $^{38}$ de terminal dönem kanser hastalarıyla yaptıkları grupla psikolojik danışmanlık uygulamasında anlam ve hayatın amacı gibi temalara yoğunlaşmışlardır. Ülkemizde ise Turgay Şirin ${ }^{39}$ tarafından gerçekleştirilen İslâmî inanç esaslarıyla bütünleştirilmiş grupla psikolojik danışmanlık uygulamasına rastlamaktayız. Literatürde özel gereksinimli çocukların ailelerine yönelik manevi yönelimli grupla danışmanlık ve rehberlik faaliyetine henüz rastlamamış bulunmaktayız. Bu durum da bu araştırmanın önemini artırmakta ve literatür için kıymetli kılmaktadır.

34 Brian C. Post, Religious and Spiritual Issues in Group Counseling: Beliefs and Preferences of University Counseling Center Clients and Therapists (Iowa: Iowa State University, Counseling Pssychology, Doktora Tezi, 2012), 38-39. Psychiatric Setting: A Pilot Study", Journal of Cognitive Psychotherapy: A International Quarterly 25/4 (2011), 1.

Christopher Christmas - Stacy M. V. Horn, "SPARC Groups: A Model for Incorporating Spiritual Psychoeducation in to Group Work", The Journal for Specialists in Group Work 37/3 (2012), 189201.

Bankole Cole - Kenneth I. Pargament, "Re-Creating Your Life: A Spiritual/Psychotherapeutic Intervention for People Diagnosed with Cancer", Psycho-Oncology 8/5 (1999), 395. William Breitbart vd., "Meaning-Centered Group Psychotherapy for Patients with Advanced Cancer: A Pilot Randomized Controlled Trial", Psycho-Oncology 19/1 (2010), 21.

39 Turgay Şirin, Bilişsel Davranış̧̧ı Psikoterapi Yaklaşımıyla Bütünleştirilmiş Dini Danışmanlık Modeli (Sakarya: Sakarya Üniversitesi, Sosyal Bilimler Enstitüsü, Doktora Tezi, 2013), x. 
304 | Sema Karagöz

\section{Konu, Amaç ve Hipotezler}

Bu araştırmanın temel konusunu manevi içerikli grup rehberliği programının özel gereksinimli çocuk sahibi annelerin olumlu ve olumsuz dini başa çıkma tutumlarına olan etkisi oluşturmaktadır. Bu çerçevede araştırmanın temel amacı özel gereksinimli çocuk sahibi annelere yönelik uygulanan manevi içerikli grup rehberliği programının olumlu dini başa çıkma ve olumsuz dini başa çıkma tutumları üzerindeki etkisini incelemektir. $\mathrm{Bu}$ çalışmada annelere uygulanan manevi içerikli grup rehberliği faaliyetiyle annelerin bu duruma bir anlam vermeleri ya da cezalandırılma gibi kendilerini rahatsız eden bir anlam biçimi söz konusu ise olumlu bir perspektifle bunun yeniden yapılandırılması ve manevi destek kaynaklarını aktif hale getirebilmeleri amaçlanmıştır. Bu amaçtan yola çıkılarak aşağıdaki hipotezler test edilmiştir.

H1: Manevi içerikli grup rehberliği programı deney grubunda olumlu dini başa çıkma düzeylerini anlamlı düzeyde artırmada etkili olacaktır.

H2: Manevi içerikli grup rehberliği programına katılmayan kontrol grubu üyelerinin olumlu dini başa çıkma düzeylerinde anlamlı düzeyde artma olmayacaktır.

H3: Manevi içerikli grup rehberliği programı deney grubunda olumsuz dini başa çıkma düzeylerini anlamlı düzeyde azaltmada etkili olacaktır.

H4: Manevi içerikli grup rehberliği programına katılmayan kontrol grubu üyelerinin olumsuz dini başa çıkma düzeylerinde anlamlı düzeyde azalma olmayacaktır.

H5: Manevi içerikli grup rehberliği programına katılan deney grubu üyelerinin program sonrası olumlu dini başa çıkma düzeyleri programa katılmayan kontrol grubu üyelerinden anlamlı düzeyde daha yüksek olacaktır.

H6: Manevi içerikli grup rehberliği programına katılan deney grubu üyelerinin program sonrası olumsuz dini başa çıma düzeyleri programa katılmayan kontrol grubu üyelerinden anlamlı düzeyde daha düşük olacaktır.

\section{Yöntem}

Bu çalışmada manevi içerikli grup rehberliğinin özel gereksinimli çocuğu olan annelerin olumlu dini başa çıkma ve olumsuz dini başa çıkma düzeylerini nasıl etkilediğini tespit etmek üzere (ön-test, son-test) 2X2'lik deneysel model kullanılmıştır; deney ve kontrol gruplarıyla zamana bağlı ölçümler gerçekleştirilmiştir. ${ }^{40}$

\subsection{Araștırma Grubu ve Süreç}

$\mathrm{Bu}$ araştırmaya katılım gösteren anneler, Bolu'da özel bir rehabilitasyon merkezinde eğitim almakta olan çeşitli özel gereksinimlilik tanısı bulunan çocuğa 
sahip 66 anne arasından seçilmiştir. Deney ve kontrol gruplarındaki katılımcılar belirlenirken programa sürekli devam etme, tanının en az iki yıl önce konmuş olması, özel gereksinimli çocuğun dört yaş ve üzeri olması kriterlerine dikkat edilmiştir. Ayrıca Dini Başa Çıkma Ölçeği'nin olumlu dini başa çıkma düzeyinden düşük; olumsuz dini başa çıkma düzeyinden ise yüksek puan alanlar sıralanarak gruplar eşitlenmeye çalışılmış ve anlamlı farklılığın olmaması önkoşulu aranmıștır. Bu koşullarda 12 anne deney 12 anne de kontrol grubunda yer almıştır. Olumlu dini başa çıkma ve olumsuz dini başa çıkma düzeyleri yönünden kontrol ve deney grupları arasında anlamlı farklılığın olup olmadığını test etmek amacıyla gerçekleştirilen Mann Whitney U testi neticesinde anlamlı bir farklılığın olmadığı tespit edilmiştir (Tablo 1 ve Tablo 2).

Tablo 1: Deney ve Kontrol Grubu Olumlu Dini Başa Çıkma Ön-Test Puanlarına İliş̧kin Mann Whitney-U Testi Sonuçları

\begin{tabular}{lccccc}
\hline Grup & N & Sira Ortalaması & Sira Toplamı & $\mathbf{U}$ & $\mathbf{p}$ \\
Deney Grubu & 12 & 11,21 & 134,50 & 56,500 &, 369 \\
Kontrol Grubu & 12 & 13,79 & 165,50 & & \\
\hline
\end{tabular}

Tablo 1'de deney ve kontrol gruplarına ait olumlu dini başa çıma puanlarına uygulanan Mann-Whitney U Testi'nin sonuçları yer almaktadır. Buna göre deney ve kontrol grubu arasında istatiksel açıdan anlamlı bir fark görülmemektedir ( $U=56,500$, $\mathrm{p}>0,05)$. Deney ve kontrol gruplarının olumlu dini başa çıkma puanlarının benzer olduğu söylenebilir.

Tablo 2: Deney ve Kontrol Grubu Olumsuz Dini Başa Çıkma Ön-Test Puanlarına İlişkin Mann Whitney-U Testi Sonuçları

\begin{tabular}{lccccc}
\hline Grup & $\mathbf{N}$ & Sira Ortalaması & Sira Toplamı & $\mathbf{U}$ & $\mathbf{p}$ \\
Deney Grubu & 12 & 11,63 & 139,50 & 61,500 &, 538 \\
Kontrol Grubu 12 & 13,38 & 160,50 & & \\
\hline
\end{tabular}

Tablo 2'de deney ve kontrol gruplarına ait olumsuz dini başa çıkma puanlarına uygulanan Mann-Whitney U Testi'nin sonuçları yer almaktadır. Buna göre deney ve kontrol grubu arasında istatiksel açıdan anlamlı bir fark görülmemektedir $(U=61,500, p>0,05)$. Deney ve kontrol gruplarının olumsuz dini başa çıkma puanlarının benzer olduğu söylenebilir.

Tüm bu kriterler esas alınarak deney ve kontrol grupları oluşturulmuştur. Gönüllü onam formunun alınmasıyla deney grubuna 10 hafta süreyle her hafta 90 dakikalık oturumlardan oluşan manevi içerikli grup rehberliği programı uygulanmıștır. Programın tamamlanmasından sonra deney ve kontrol gruplarına son-testler uygulanmıştır.

Manevi içerikli grup rehberliği programının birinci oturumu grup üyelerinin tanışması ve bilgilendirilmesi üzerinedir. İkinci oturumda sabır ve şükür kavramları 
306 | Sema Karagöz

hakkında bilgi sunulmuş ve günlük hayatla bağlantı kurabilmeleri sağlanmıștır. Üçüncü oturumda tanıyı öğrendikten sonraki duygu ve düşünceleri üzerine konuşularak bugün geldikleri noktayla karșılaştırma yapabilmeleri sağlanmıștır. Dördüncü oturumda özel gereksinimli çocuk sahibi olmaya yüklenen anlam konusu işlenmiştir. Beşinci oturumda stres ve stresle etkili başa çlkabilmeye yer verilmiştir. Altıncı oturumda sorumluluk ve tevekkül kavramları işlenirken yedinci oturumda sosyal ve manevi destek mekanizmaları üzerine paylaşımda bulunulmuştur. Sekizinci oturumda endişeler ve bunlarla başa çıkabilme konusu işlenmiştir. Dokuzuncu oturumda umut ve iyimserlikten bahsedilerek onuncu oturum değerlendirmelerle tamamlanmıştır.

\subsection{Veri Toplama Araçları}

Araştırmanın konusuna, amacına ve problemlerine uygun olarak kişisel bilgi formu ve dini başa çıkma ölçeği kullanılmıştır. Katılımcıların sosyo-demografik ve kişisel özelliklerine ilişskin bilgi sahibi olabilmek amacıyla Kişisel Bilgi Formu sunulmuştur. Ardından da olumlu ve olumsuz dini başa çıma düzeylerini tespit edebilmek için Dini Başa Çıkma Ölçeği uygulanmıştır. Bu ölçekler, katılımcılara öntest ve son-test olmak üzere iki kez verilmiştir.

Kişisel Bilgi Formu: Araştırmaya katılan bireylerin kişisel ve sosyodemografik özelliklerini belirleyebilmek amacıyla araştırmacı tarafından oluşturulmuştur. Kişisel Bilgi Formu aracıllğıyla ilişkisel ya da zamana bağlı bir ölçüm yapmak değil; bireysel değișkenler belirlenerek grupları kontrol altına alabilmek hedeflenmiştir. Bu formda yaş, medeni durum, bir işte çalışıp/çalışmama, gelir durumu, çocuk sayısı, çocuğun tanısı, kaçıncı çocuk olduğu, yaşı, cinsiyeti, tanının ne kadar zaman önce konulduğu, daha öncesinde benzer bir programa katılıp katılmadıkları, dine bakış açılarına ilişkin sorular yer almıştır.

Dini Başa Çıkma Ölçeği: Dini Başa Çıkma Ölçeği (DBÇÖ), bireyler sıkıntı verici durumlar deneyimlediğinde başvurdukları dini içerikli başa çıkma stillerini ve bu stillere ne sıklıkta başvurduklarını tespit etmektedir. Pargament, Koenig ve Perez $^{41}$ tarafından geliştirilen ölçek, Ayten'in ${ }^{42}$ çalışmalarıyla Türkçeye kazandırılmıştır. Ölçeğin yapı geçerliliğini test etmek için yapılan faktör analiziyle KMO değeri ,799; faktör analizine dayalı korelasyonel anlamlılı̆ğ gösteren Bartlett's Test of Sphericity değeri ise $\left(x^{2}\right) 1976,212(p=, 000)$ bulgulanmıştır. Yapılan bu faktör analizi neticesinde ölçek 33 madde ve 9 alt boyuttan meydana gelmiştir. Ölçeğin güvenirliğini tespit etmek için yapılan iç tutarlılık analizi neticesinde ise ölçek geneli ve alt boyutları için Cronbach Alpha değerleri şu şekilde bulgulanmıştır: Ölçek geneli ,807, Allah'a yönelme ,867, hayra yorma ,840, kişilerarası dini hoşnutsuzluk ,731, dini yalvarma ,676, dini yakınlaşma ,613, dini dönüşüm ,508, manevi hoşnutsuzluk ,580,

41 Kenneth I. Pargament vd., "The Many Methods of Religious Coping: Development and Initial Validation of the RCOPE", Journal of Clinical Psychology 56 (2000), 519-543.

42 Ali Ayten, Tanrı'ya Sığınmak (İstanbul: İz Yayıncılık, 2012), 29-32. 
şerre yorma ,521 ve dini istikamet ,500. Son olarak dokuz alt boyuta yeniden faktör analizi uygulanmıştır. Bunun neticesinde olumlu dini başa çıkma ve olumsuz dini başa çıkma olmak üzere iki üst boyut elde edilmiştir.

$\mathrm{Bu}$ araştırmada ise Batan'ın ${ }^{43}$ çalışmalarıyla 26 soruya indirdiği Dini Başa Çıkma Ölçeği kullanılmıştır. Batan (2016) ölçeğe uyguladığı faktör analizleri neticesinde Kaiser-Mayer-Olkin (KMO) değerini ,903; Barlett's Test of Sphericity değerini $\left(x^{2}\right) 7407,290(p=, 000)$ bulgulamıștır. Ölçeğin 6 boyutlu olduğu ve varyansın \% 68,777'sini açıkladığı tespit edilmiştir. İç tutarlılık analizi neticesinde ölçek geneli ve alt boyutlar için elde edilen Cronbach Alpha değerleri sirayla şu şekildedir: ölçek genel $\alpha=, 862$; Hayra Yorma/Dini Yalvarma $\alpha=, 920$; Allah'a Yönelme $\alpha=, 893$; Serre Yorma/Manevi Hoşnutsuzluk $\alpha=, 802$; Kişilerarası Dini Hoşnutsuzluk $\alpha=, 839 ;$ Dini İstikamet Arayışı $\alpha=, 709$; Dini Yakınlaşma $\alpha=, 617$. Bu altı boyuta tekrar faktör analizi uygulanarak olumlu ve olumsuz dini başa çıkma olmak üzere iki boyut elde edilmiştir. Hayra yorma/dini yalvarma, Allah'a yönelme, dini istikamet arayışı, dini yakınlaşma alt boyutları olumlu dini başa çıkma boyutu kapsamında ele alınmaktadır. Şerre yorma/manevi hoşnutsuzluk ve kişilerarası dini hoşnutsuzluk alt boyutları ise olumsuz dini başa çıkma boyutu altında yer almaktadır.

\subsection{Verilerin Çözümlenmesi}

Araştırma verilerini çözümlemek amacıyla non-parametrik testlerden 'MannWhitney U' ile 'Wilcoxon İşaretli Sıralar Testi' kullanılmıştır. Bulguların değerlendirilmesinde .05 anlamlılık düzeyi aranmıştır. İstatiksel işlemler SPSS programı aracılığıyla gerçekleştirilmiştir.

\section{Bulgular}

Bu bölümde araştırmanın hipotezlerini test etmek amacıyla gerçekleştirilen istatiksel işlemler neticesinde elde edilen bulgulara yer verilmiştir.

Tablo 3: Olumlu Dini Başa Çıkma Alt Boyutu Ön-Test ve Son-Test Puanları

\begin{tabular}{lccccc}
\hline & N & Ortalama & S. Sapma & En Düşük & En Yüksek \\
Deney Grubu Ön-Test & 12 & 4,07 &, 25 & 3,67 & 4,56 \\
Deney Grubu Son-Test & 12 & 4,42 &, 13 & 4,17 & 4,67 \\
Kontrol Grubu Ön-Test & 12 & 4,17 &, 25 & 3,83 & 4,50 \\
Kontrol Grubu Son-Test & 12 & 4,15 & \multirow{2}{*}{, 20} & 3,83 & 4,56 \\
\hline
\end{tabular}

Tablo 3 incelendiğinde deney grubu katılımcılarının olumlu dini başa çıkma düzeyi puan ortalamaları ön-testte 4,07 iken son-testte 4,42 olarak tespit edilmiştir.

43 Nazlı Batan, Yetișkinlerde Psikolojik Dayanıklılık ve Dini Bașa Çıkmanın Yașam Doyumuna Etkileri (İstanbul: Marmara Üniversitesi, Sosyal Bilimler Enstitüsü, Doktora Tezi, 2016), 98-110. 
Dolayısıyla deney grubu katılımcılarının olumlu dini başa çıkma puanlarında artma gerçekleşmiştir. Kontrol grubu katılımcılarının olumlu dini başa çıkma düzeylerine ilișkin puan ortalamaları ise ön-testte 4,17 iken son-testte 4,15 olarak tespit edilmiştir. Bu sonuca göre kontrol grubu katılımcılarının olumlu dini başa çıkma puanlarında azalma meydana gelmiştir.

Araştırmanın birinci hipotezi olan H1'i test amacıyla yapılan "Wilcoxon İşaretli Sıralar Testi' sonuçları aşağıda yer almaktadır.

Tablo 4: Ön-Test-Son-Test Deney Grubu "Olumlu Dini Başa Çıkma" Verilerinin “Wilcoxon İşaretli Sıralar Testi” Sonuçları

\begin{tabular}{lccccc}
\hline Sontest-Öntest & $\mathbf{n}$ & Sıra Ortalaması & Sıra Toplamı & $\mathbf{z}$ & $\mathbf{p}$ \\
Negatif Sıra & 0 &, 00 &, 00 & &, 002 \\
Pozitif Sıra & 12 & 6,50 & 78,00 & $-3,066$ & \\
Eşit & 0 & & & & \\
\hline
\end{tabular}

Tablo 4'te görüldüğü gibi uygulamaya katılan annelerin işlem sonrasında olumlu dini başa çıkma düzeylerinde son-test puanları lehine anlamlı bir fark olduğu görülmektedir $(\mathrm{z}=-3,066, \mathrm{p}<.01)$. Bu sonuca göre uygulanan program annelerin olumlu dini başa düzeyini anlamlı düzeyde yükseltmiștir.

Araştırmanın ikinci hipotezi olan H2'yi test amacıyla yapılan "Wilcoxon İşaretli Sıralar Testi' sonuçları aşağıda yer almaktadır.

Tablo 5: Ön-Test-Son-Test Kontrol Grubu "Olumlu Dini Başa Çıkma" Verilerinin “Wilcoxon İşaretli Sıralar Testi” Sonuçları

\begin{tabular}{lcclcc}
\hline Sontest-Öntest & $\mathbf{n}$ & Sıra Ortalaması & Sıra Toplamı & $\mathbf{z}$ & $\mathbf{p}$ \\
Negatif Sıra & 5 & 8,30 & 41,50 & &, 844 \\
Pozitif Sıra & 7 & 5,21 & 36,50 &,- 197 & \\
Eșit & 0 & & & & \\
\hline
\end{tabular}

Tablo 5 incelendiğinde uygulamaya katılmayan annelerin olumlu dini başa çıkma düzeylerinde anlamlı farklılık olmadığı görülmektedir $(\mathrm{z}=-, 197, \mathrm{p}>, 05)$. 
Tablo 6: Olumsuz Dini Başa Çıkma Alt Boyutu Ön-Test ve Son-Test Puanları

\begin{tabular}{|c|c|c|c|c|c|}
\hline & $\mathbf{N}$ & Ortalama & S. Sapma & En Düşük & En Yüksek \\
\hline Deney Grubu Ön-Test & 12 & 1,90 & ,28 & 1,50 & 2,38 \\
\hline Deney Grubu Son-Test & 12 & 1,46 & 18 & 1,13 & 1,88 \\
\hline Kontrol Grubu Ön-Test & 12 & 1,98 & 30 & 1,38 & 2,50 \\
\hline Kontrol Grubu Son-Test & 12 & 1,95 & 22 & 1,50 & 2,13 \\
\hline
\end{tabular}

Tablo 6 incelendiğinde deney grubu katılımcllarının olumsuz dini başa çıkma düzeyi puan ortalamaları ön-testte 1,90 iken son-testte 1,46 olarak tespit edilmiștir. Dolayısıyla deney grubu katılımcılarının olumsuz dini başa çıkma puanlarında azalma gerçekleşmiştir. Kontrol grubu katılımcılarının olumsuz dini başa çıkma düzeylerine ilişkin puan ortalamaları ise ön-testte 1,98 iken son-testte 1,95 olarak tespit edilmiştir. Bu sonuca göre kontrol grubu katılımcılarının olumsuz dini başa çıkma puanlarında azalma meydana gelmiştir.

Araştırmanın üçüncü hipotezi olan H3'ü test amacıyla yapılan "Wilcoxon İşaretli Sıralar Testi' sonuçları aşağıda yer almaktadır.

Tablo 7: Ön-Test-Son-Test Deney Grubu “Olumsuz Dini Başa Çıkma” Verilerinin “Wilcoxon İşaretli Sıralar Testi” Sonuçları

\begin{tabular}{lccccc}
\hline Sontest-Öntest & $\mathbf{n}$ & Sıra Ortalaması & Sıra Toplamı & $\mathbf{z}$ & $\mathbf{p}$ \\
Negatif Sıra & 11 & 6,00 & 66,00 & &, 003 \\
Pozitif Sıra & 0 &, 00 &, 00 & $-2,944$ & \\
Eşit & 1 & & & & \\
\hline
\end{tabular}

Tablo 7'de görüldügü gibi uygulamaya katılan annelerin ișlem sonrasında olumsuz dini başa çıkma düzeylerinde son-test puanları lehine anlamlı bir fark olduğu görülmektedir $(\mathrm{z}=-2,944, \mathrm{p}<.01)$. Bu sonuca göre uygulanan program annelerin olumsuz dini başa düzeyini anlamlı düzeyde azaltmıştır.

Araştırmanın dördüncü hipotezi olan H4'ü test amacıyla yapılan "Wilcoxon İşaretli Sıralar Testi' sonuçları aşağıda yer almaktadır.

Tablo 8: Ön-Test-Son-Test Kontrol Grubu “Olumsuz Dini Başa Çıkma” Verilerinin “Wilcoxon İşaretli Sıralar Testi” Sonuçları

\begin{tabular}{lccccc}
\hline Sontest-Öntest & $\mathbf{n}$ & Sıra Ortalaması & Sıra Toplamı & $\mathbf{z}$ & $\mathbf{p}$ \\
Negatif Sıra & 3 & 5,83 & 17,50 & &, 550 \\
Pozitif Sıra & 4 & 2,63 & 10,50 &,- 598 & \\
Eşit & 5 & & & & \\
\hline
\end{tabular}


Tablo 8 incelendiğinde uygulamaya katılmayan annelerin olumsuz dini başa çıkma düzeylerinde anlamlı farklılık olmadığı görülmektedir $(\mathrm{z}=-, 598, \mathrm{p}>, 05)$.

Araştırmanın beşinci hipotezi olan H5'i test amacıyla yapılan "Mann Whitney U Test' sonuçları aşağıda yer almaktadır.

Tablo 9: Deney ve Kontrol Grubu Olumlu Dini Başa Çıkma Son-Test Puanlarına İlişkin Mann Whitney-U Testi Sonuçları

\begin{tabular}{lccccc}
\hline Grup & N & Sira Ortalaması & Sira Toplamı & $\mathbf{U}$ & $\mathbf{p}$ \\
Deney Grubu & 12 & 16,67 & 200,00 & 22,000 &, 004 \\
Kontrol Grubu 12 & 8,33 & 100,00 & & \\
\hline
\end{tabular}

Tablo 9 incelendiğinde deney ve kontrol grupları olumlu dini başa çlkma düzeyi son-test puan ortalamalarına ilişkin farklılığın istatiksel açıdan anlamlı olduğu görülmüştür $(U=22,000 \mathrm{p}<, 05)$.

Araştırmanın altıncı hipotezi olan H6'yı test amacıyla yapılan “Mann Whitney U Test' sonuçları aşağıda yer almaktadır.

Tablo 10: Deney ve Kontrol Grubu Olumsuz Dini Başa Çıkma Son-Test Puanlarına İlişkin Mann Whitney-U Testi Sonuçları

\begin{tabular}{lccccc}
\hline Grup & N & Sira Ortalaması & Sira Toplamı & $\mathbf{U}$ & $\mathbf{p}$ \\
Deney Grubu & 12 & 7,17 & 86,00 & 8,000 &, 000 \\
Kontrol Grubu & 12 & 17,83 & 214,00 & & \\
\hline
\end{tabular}

Tablo 10 incelendiğinde deney ve kontrol grupları olumsuz dini başa çlkma düzeyi son-test puan ortalamalarına ilişkin farklılığın istatiksel açıdan anlamlı olduğu görülmüştür $(U=8,000 \mathrm{p}<, 05)$.

\section{Sonuç}

Olumlu dini başa çıkma düzeylerinin artırılmasına ve olumsuz dini başa çıkma düzeylerinin azaltılmasına yönelik hazırlanan manevi içerikli grup rehberliği programının, özel gereksinimli çocuk sahibi anneler üzerindeki etkisini inceleyen bu araştırmanın neticesinde ortaya çıkan bulgular bu başlık altında tartışılmış ve yorumlanmıștır.

Elde edilen bulgulardan yola çıkarak denilebilir ki; manevi içerikli grup rehberliği programına katılan annelerin olumlu dini başa çıkma düzeylerinde anlamlı düzeyde artma ve olumsuz dini başa çıkma düzeylerinde anlamlı düzeyde azalma meydana gelmiştir. Ayrıca program sonunda deney grubu ve kontrol grubu katılımcılarının olumlu dini başa çıkma ve olumsuz dini başa çıkma puanları arasında anlamlı düzeyde değişim gerçekleştiği tespit edilmiştir. Deney grubu 
katılımclarındaki bu değişimin manevi içerikli grup rehberliği uygulamasından kaynaklandığı söylenebilir (Tablo 4,5,7,8,9,10).

Tecrübe edilen bir durumu hayra yorma ya da Yaratıcı'yla iş birliği halinde hareket etme gibi yönelimler daha iyi psikolojik sağlıkla ilişkilidir. Yaratıcı'nın cezalandırdığı ya da kendine yardım etmediği gibi bakış açıları ise içsel çatışmaları artırmakta ve psikolojik iyilik halini olumsuz yönde etkilemektedir. ${ }^{44}$ Bu bağlamda gerçekleștirilen araştırmalar incelendiğinde, Yaratıcı'ya güven duyan, yaşananlarda hikmetli bir anlam bulmaya çalışan ve diğer din mensuplarıyla iyi ilişskiler geliştirme çabasında olan dini başa çıkma tutumunun psikolojik sağlığı koruyucu ve mücadele sürecinde destekleyici rol oynadığı görülmektedir. ${ }^{45}$ Diğer yandan olumsuz dini başa çıkmanın psikolojik sağlık üzerindeki etkilerini inceleyen araştırmalara bakarsak örneğin; Abu-Raiya, Pargament, Weissberger ve Exline ${ }^{46}$ üniversite öğrencilerine manevi çatışma ölçeğini uygulamışlardır. Araştırmanın neticesinde cezalandırıcı, mesafeli ve acımasız bir Tanrı imajıyla yüksek düzey psikolojik sıkıntı arasında ilişki olduğunu tespit etmişlerdir. Bu araştırma bulgularına benzer şekilde olumsuz dini başa çıkma etkinliklerinin psikolojik iyilik halini negatif yönde etkilediğini ifade eden

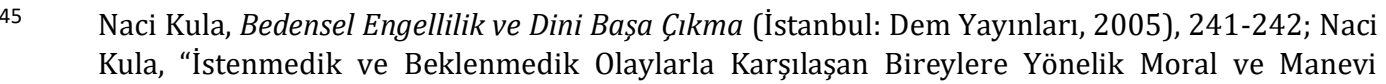
Desteğin Önemi”, Din Bilimleri Akademik Araştırma Dergisi 6/2 (2006), 73; Michelle J. Pearce, Religious Coping and Belief Systems Associated with the Well-Being and Experience of Caregivers of Terminally Ill Patients (Connecticut: Yale University, Doctor of Philosophy, Doktora Tezi, 2007), i-ii; Elif Kara, "Zihinsel Engelli Çocukları Olan Ailelerin Çocuklarının Durumunu Dini Açıdan Değerlendirmeleri", On Dokuz Mayıs Üniversitesi İlahiyat Fakültesi Dergisi 26/27 (2008), 330; David Rosmarin vd., "Religion as a Predictor of Psychological Distress in Two Religious Communities", Cognitive Behaviour Therapy 38/1 (2009), 54; David Rosmarin vd., "The Role of Religiousness in Anxiety, Depression and Happiness in a Jewish Community Sample: A Preliminary Investigation", Mental Health, Religion \& Culture 12/2 (2009), 97; Randy Hebert vd., "Positive and Negative Religious Coping and Well-Being in Women with Breast Cancer", Journal of Palliative Medicine 12/6 (2009), 537; Ayșe Şentepe, Yaşllık Döneminde Temel Problemler ve Dini Başa Çıkma (İstanbul: Marmara Üniversitesi, Sosyal Bilimler Enstitüsü, Yüksek Lisans Tezi, 2009), 61; Judy A. Schreiber, "Image of God: Effect on Coping and Psychospiritual Outcomes in Early Breast Cancer Survivors", Oncology Nursing Forum 38/3 (2011), 293; Ayten, Tanri'ya Siğınmak, 132; Ali Ayten vd., "Dini Başa Çıkma, Şükür ve Hayat Memnuniyeti İlișkisi: Hastalar, Hasta Yakınları ve Hastane Çalışanları Üzerine Bir Araştırma”, Din Bilimleri Akademik Araştırma Dergisi 12/2 (2012), 45; Kevin L. Rand vd., "Illness Appraisal, Religious Coping and Psychological Responses in Men with Advanced Cancer", Support Care Cancer 20 (2012), 1719; Sema Eryücel, "Yaşam Olayları ve Olumlu Dini Başa Çıkma", Mustafa Kemal Üniversitesi Sosyal Bilimler Enstitüsü Dergisi 10/23 (2013), 251; Hisham Abu-Raiya vd., "Contribution of Religious Coping and Social Support to the Subjective Well-Being of Israeli Muslim Parents of Children with Cancer: A Priliminary Study", Health and Social Work 40/3 (2015), 83; Mebrure Doğan, "Engelli Çocuğa Sahip Ebeveynler ile Sağlıklı Çocuk Sahibi Ebeveynlerin Dini Başa Çıkma, Umut ve Sabır Düzeylerinin Karşılaștırılması", İnsan ve Toplum Bilimleri Araştırma Dergisi $5 / 8$ (2016), 3214; Veysel Uysal vd., "Dini Başa Çılkma ile Umut, Hayat Memnuniyeti ve Psikolojik Sağlamlık Arasındaki Etkileșim Üzerine Bir Araștırma”, Marmara Üniversitesi İlahiyat Fakültesi Dergisi 52 (2017), 139; Behlül Tokur, Imtihan Psikolojisi Var Olmanın Hakkını Vermek: Imtihan (Ankara: Fecr Yayınları, 2018), 143-144; Zeynep Özcan, "Mülteci Öğrencilerin Kültürel Uyumları ile Dini Başa Çıkmaları Arasındaki İlișki Üzerine Bir Araştırma”, Cumhuriyet İlahiyat Dergisi 23/1 (2019), 129. Hisham Abu-Raiya vd., "An Emprical Examination of Religious/Spiritual Struggle among Israeli Jews", The International Journal for the Psychology of Religion 26 (2016), 61-62. 
başka araştırmalar da mevcuttur. ${ }^{47} \mathrm{Bu}$ araştırma bulgularında hareketle denilebilir ki; manevi içerikli grup rehberliği neticesinde deney grubu üyelerinin psikolojik iyilik halleri artarken içsel çatışmalarında azalma meydana gelmiştir. Uygulamanın içeriğinde yer alan özel gereksinimli çocuk sahibi olmaya bir anlam bulma ya da daha öncesinde yüklenen olumsuz nitelikli anlamı daha pozitif bir bakış açısıyla yeniden yapılandırmaya gitme, suçluluk duygularını azaltmaya çalışma, dua etmek gibi manevi açıdan destekleyici uygulamalara yer verme katılımcılar üzerinde etkili olarak manevi iç barışıklığın sağlanmasına katkıda bulunmuş olabilir.

Manevi iyilik halini destekleyerek manevi çatışmaları azaltmayı amaçlayan çeşitli araştırmalar literatürde bulunmaktadır. Anlam arayışının güçlü bir biçimde kendini gösterdiği durumlardan birisi de kanser tanısı alınmasıdır. Kanser hastası ve yakınlarının psikolojik uyum ve dirençlerini güçlendirebilmek için çalışmalar yapılmaktadır. Örneğin; Sun ve diğerleri ${ }^{48}$ manevi temalardan oluşan dört oturumluk programı kanser tanılı hastalara uygulamışlar ve katılımcıların iç barışıklık boyutunda artış meydana geldiğini tespit etmişlerdir. Benzer şekilde, Holtmaat ve diğerleri ${ }^{49}$ de kanser tanılı hastalar için anlam temelli psikoterapi programı hazırlamışlar ve araştırmanın neticesinde üyelerin anlamlılık düzeylerinde artış bulgulamışlardır. Sankhe ve diğerleri ${ }^{50}$ ise gerçekleştirdikleri araştırmada kanser hasta ve yakınlarına manevi içerikli destek programı uygulamışlar ve programın manevi iyilik halini artırdığını tespit etmişlerdir. Bu deneysel araştırma bulguları bu çalışmanın neticesinde elde edilen olumlu dini başa çıkma düzeyinde artma ve olumsuz dini başa çıkma düzeyinde azalma bulgularıyla paralellik arz etmektedir. Çünkü meydana gelen bu değişimle katılımcıların manevi iyilik hallerinin arttığı ve çatışmalarının çözümlenmesine destek olunduğu düşünülmektedir.

$47 \quad$ McConnell Kelly vd., "Examining the Links between Spiritual Struggles and Symptoms of Psychopathology in a National Sample", J Clin Psychol 62 (2006), 1469; Pearce, Religious Coping, i-ii; Hebert vd., "Positive and Negative Religious Coping", 537; Rosmarin vd., "Religion as a Predictor", 54; Rand vd., "Illness Appraisal”, 1719; Şentepe, Yaşlılık Döneminde Temel Problemler, 61; Ayten, Tanrı'ya Sığınmak, 132; Beyazıd Y. Seyhan, "Üniversite Öğrencilerinde Tanrı Tasavvuru ve Psikolojik İyi Olma Hali Arasındaki İlişkiler", Cumhuriyet Üniversitesi İlahiyat Fakültesi Dergisi 18/1 (2014), 65; Hisham Abu-Raiya vd., "Prevalence, Predictors and Implications of Religious/Spiritual Struggles among Muslims", Journal for the Scientific Study of Religion 54/4 (2015), 631; Hisham Abu-Raiya vd., "Robust Links between Religious/Spiritual Struggles, Psychological Distress and Well-Being in a National Sample of American Adults", American Journal of Orthopsychiatry 85/6 (2015), 565; Hisham Abu-Raiya vd., "Understanding and Addressing Religious and Spiritual Struggles in Health Care", Health \& Social Work 40/4 (2015), 126; Mabel Oti-Boadi - Kwaku O. Asante, "Psychological Health and Religious Coping of Ghanaian Women with Infertility", Bio Psycho Medicine 11/20 (2017), 1; Uysal vd., "Dini Başa Çıkma ile Umut", 139. Virginia Sun vd., "Palliative Care and Spiritual Well-Being in Lung Cancer Patients and Family Caregivers", Psycho-Oncology 25 (2016), 1448.

Karen Holtmaat vd., "Moderators of the Effects of Meaning-Centered Group Psychotherapy in Cancer Survivors on Personal Meaning, Psychological Well-Being and Distress", Support Care Cancer 25/11 (2017), 3385. 
Uygulamış olduğumuz manevi içerikli grup rehberliği programında özel gereksinimleri bulunan bir çocuğun annesi olmaya yüklenen anlama, kabul ve uyumu kolaylaştırmaya yönelik Peygamber kıssalarına, manevi direnci ve umudu artırabilmek için dua etme etkinliğine, suçluluk duygularının ya da manevi çatışmaların açıklıkla dile getirilmesine yer verilmiştir. Böylece duygu ve düşüncelerini güvenli bir ortamda ifade ederek, manevi barışıklıklarını destekleyici bir anlam oluşturmaya giderek ve kutsallık atfettikleri peygamberlerin de çeşitli sıkıntılar yaşadıklarından haberdar olarak cezalandırılmışlık ve yalnızlık hissinden sıyrılmaları sağlanmaya çalışılmıştır. Tüm bunlar uygulamanın etkililiğini artırıcı birer faktör olmuş olabilir. Dolayısıyla özel gereksinimli çocuğu olan ailelere sunulacak manevi yönelimli profesyonel destek hizmetleriyle onların yaşama daha uyumlu, barışık ve güçlü devam etmelerine katkıda bulunulabilir. Bununla birlikte ulusal ve uluslararası literatürde özel gereksinimli çocukların ebeveynlerine yönelik grupla psikolojik danışmanlık ve rehberlik bağlamında kontrollü deneysel çalışmalara henüz rastlanmayışı da dikkat çekicidir.

Sonuç itibarıyla, olumlu dini başa çıkma düzeyini artırmaya ve olumsuz dini başa çıkma düzeyini azaltmaya yönelik gerçekleştirilen manevi içerikli grup rehberliği uygulaması olumlu yönde sonuç vermiştir. Deney grubunda yer alan özel gereksinimli çocuk sahibi annelerin olumlu dini başa çlkma puanlarında istatiksel olarak anlamlı düzeyde artma sağlanırken olumsuz dini başa çıkma puanlarında istatiksel olarak anlamlı düzeyde azalma görülmüştür. Bu sonuçlara dayanarak aşağıdaki önerilerde bulunulmuștur:

1. Anneler temel alınarak gerçekleştirilen manevi içerikli grup rehberliği programı babalar ve kardeşler için de düzenlenebilir. Ayrıca anne-babaların bir arada yer aldığı ebeveyn programları biçiminde de hazırlanarak etkililiği incelenebilir.

2. Manevi içerikli grup rehberliği programının tamamlanmasından itibaren 6 ve 12 ay sonraki etkililiğini tespit etmek üzere izleme çalışmaları gerçekleştirilebilir.

3. Bu araştırmanın içeriğinde yer verilen manevi unsurlar daha ziyade İslam Dini referanslıdır ve katılımcılar da bu bakış açısına sahiptir. Gerçekleştirilecek yeni araştırmalar diğer din mensupları veya inanç sahiplerini göz önünde bulundurarak hazırlanabilir.

4. Manevi içerikli grup rehberliği programının oturum sayısı artırılabilir.

5. Katılımcılara ölçme aracı olarak manevi iyi oluş ölçeği uygulanabilir.

\section{Kaynakça}

Abu-Raiya, Hisham vd. "An Emprical Examination of Religious/Spiritual Struggle among Israeli Jews". The International Journal for the Psychology of Religion 26 (2016), 61-79. https://doi.org/10.1080/10508619.2014.1003519

Abu-Raiya, Hisham vd. "Contribution of Religious Coping and Social Support to the Subjective Well-Being of Israeli Muslim Parents of Children with Cancer: A Priliminary Study". Health and Social Work 40/3 (2015), 83-91. https://doi.org/10.1093/hsw/hlv031 
Abu-Raiya, Hisham vd. "Prevalence, Predictors and Implications of Religious/Spiritual Struggles among Muslims". Journal for the Scientific Study of Religion 54/4 (2015), 631-648. https://doi.org/10.1111/jssr.12230

Abu-Raiya, Hisham vd. "Robust Links between Religious/Spiritual Struggles, Psychological Distress and Well-Being in a National Sample of American Adults". American Journal of Orthopsychiatry 85/6 (2015), 565-575. https://doi:10.1037/ort0000084

Abu-Raiya, Hisham vd. "Understanding and Addressing Religious and Spiritual Struggles in Health Care". Health \& Social Work 40/4 (2015), 126-134. https://doi.org/10.1093/hsw/hlv055

Akandere, Mehibe vd. "Zihinsel ve Fiziksel Engelli Çocuğa Sahip Anne ve Babaların Yaşam Doyumu ve Umutsuzluk Düzeylerinin İncelenmesi”. Selçuk Üniversitesi Sosyal Bilimler Enstitüsü Dergisi 22 (2009), 23-32.

Andreyko, Bogdanna. "The Emotional State of Parents in the Structure of the Stages of the Experience of Having a Child with Developmental Disabilities". Journal of Education Culture and Society 2 (2016), 150-157. https://doi.org/10.15503/jecs20162.150.157

Ayten, Ali. Tanrı'ya Sığınmak. İstanbul: İz Yayıncılık, 2012.

Ayten, Ali vd. "Dini Başa Çıkma, Şükür ve Hayat Memnuniyeti İlişkisi: Hastalar, Hasta Yakınları ve Hastane Çalışanları Üzerine Bir Araștırma". Din Bilimleri Akademik Araştırma Dergisi 12/2 (2012), 45-49.

Batan, Nazlı. Yetişkinlerde Psikolojik Dayanıklılık ve Dini Başa Çıkmanın Yaşam Doyumuna Etkileri. İstanbul: Marmara Üniversitesi, Sosyal Bilimler Enstitüsü, Doktora Tezi, 2016.

Betman, Johannah E. M. Parental Grief When a Child Is Diagnosed with a Life-Threatening Chronic-Illness: The Impact of Gender, Perceptions and Coping Strategies. New Zealand: University of Canterbury, Master of Arts in Psychology, Yüksek Lisans Tezi, 2006.

Bıçak, Nilgün. Otizmli Çocukların Annelerinin Yaşadıklarının Belirlenmesi. Bolu: Abant İzzet Baysal Üniversitesi, Sosyal Bilimler Enstitüsü, Yüksek Lisans Tezi, 2009.

Bjorck, Jeffrey P. - Thurman, John W. "Negative Life Events, Patterns of Positive and Negative Religious Coping and Psychological Functioning". Journal for the Scientific Study of Religion 46/2 (2007), 159-167. https://www.jstor.org/stable/4621966

Büyüköztürk, Şener vd.. Bilimsel Araştırma Yöntemleri. Ankara: Pegem Akademi, 2008.

Cavkaytar, Atilla vd.. Özel Eğitimde Aile Eğitimi ve Rehberliği. Ankara: Vize Basın Yayın, 2013.

Christmas, Christopher - Horn, Stacy M. V. "SPARC Groups: A Model for Incorporating Spiritual Psychoeducation in to Group Work". The Journal for Specialists in Group Work 37/3 (2012), 170-201. https://doi.org/10.1080/01933922.2012.690833

Cole, Bankole - Pargament, Kenneth I. "Re-Creating Your Life: A Spiritual/Psychotherapeutic Intervention for People Diagnosed with Cancer". Psycho-Oncology 8/5 (1999), 395407. $\quad$ https://doi.org/10.1002/(sici)1099-1611(199909/10)8:5<3C395::aidpon408>3E3.0.co;2-b

Dawson, Julia Shank. A Spiritual Resource of Hope and Healing for Parents of Seriously Ill Children. New Jersey: Drew University, 2008.

Doğan, Mebrure. "Engelli Çocuğa Sahip Ebeveynler ile Sağlıklı Çocuk Sahibi Ebeveynlerin Dini Başa Çıkma, Umut ve Sabır Düzeylerinin Karşılaştırılması". İnsan ve Toplum Bilimleri Araştırmaları Dergisi $\quad 5 / 8 \quad$ (2016), 3214-3245. https://doi.org/10.15869/itobiad.283094 
Dzubay, Suzan K. Parental Grief, Coping Strategies and Challenges When a Child Has Autism Spectrum Disorder. Wisconsin: The Graduate School University of Wisconsin-Stout, Family Studies and Human Development, Yüksek Lisans Tezi, 2011.

Eryücel, Sema. "Yaşam Olayları ve Olumlu Dini Başa Çıkma". Mustafa Kemal Üniversitesi Sosyal Bilimler Enstitüsü Dergisi 10/23 (2013), 251-271.

Gray, David E. "Coping over Time: The Parents of Children with Autism". Journal of Intellectual Disability Research 50/12 (2006), 970-976. https://doi.org/10.1111/j.13652788.2006.00933.x

Güneş, Ahmet. Otizm ve Otistik Çocukların Eğitimi. İzmir: İlya İzmir Yayınevi Matbaası, 2005.

Hebert, Randy vd. "Positive and Negative Religious Coping and Well-Being in Women with Breast Cancer". Journal of Palliative Medicine 12/6 (2009), 537-545. https://doi.org/10.1089/jpm.2008.0250

Heiman, Tali - Berger, Ornit. "Parents of Children with Asperger Syndrome or with Learning Disabilities: Family Environment and Social Support". Research in Developmental Disabilities 29/4 (2007), 289-300. https://doi.org/10.1016/j.ridd.2007.05.005

Heward, William L. Exceptional Children an Introduction to Special Education. New Jersey: Pearson Education, 2009.

Holtmaat, Karen vd. "Moderators of the Effects of Meaning-Centered Group Psychotherapy in Cancer Survivors on Personal Meaning, Psychological Well-Being and Distress". Support Care Cancer 25/11 (2017), 3385-3393. http://dx.doi.org/10.1007/s00520017-3757-x

Hunt, Nancy - Marshall, Kathleen. Exceptional Children and Youth. Boston: Houghton Mifflin Company, 1999.

Kandel, Isack - Merrick, Joav Merrick. "The Birth of a Child with Disability". The Scientific World Journal 3 (2003), 241-750. https://doi.org/10.1100\%2Ftsw.2003.63

Kara, Elif. "Zihinsel Engelli Çocukları Olan Ailelerin Çocuklarının Durumunu Dini Açıdan Değerlendirmeleri”. On Dokuz Mayıs Üniversitesi Illahiyat Fakültesi Dergisi 26/27 (2008), 317-331.

Karagöz, Sema. Otistik Çocukların Anne Babalarında Anlamlandırma ve Dini Başa Çıkma. İstanbul: Marmara Üniversitesi, Sosyal Bilimler Enstitüsü, Yüksek Lisans Tezi, 2010.

Kula, Naci. Bedensel Engellilik ve Dini Başa Çıkma. İstanbul: Dem Yayınları, 2005.

Kula, Naci. "İstenmedik ve Beklenmedik Olaylarla Karşılaşan Bireylere Yönelik Moral ve Manevi Desteğin Önemi”. Din Bilimleri Akademik Araştırma Dergisi 6/2 (2006), 73-94.

Küçüker, Sevgi. "Erken Eğitimin Gelişimsel Geriliği Olan Çocukların Anne-Babalarının Stres ve Depresyon Düzeyleri Üzerindeki Etkisinin İncelenmesi". Özel Eğitim Dergisi 1/3 (2001), 1-11. https://doi.org/10.1501/Ozlegt_0000000055

Lindholm, Michelle M. Stress, Coping and Quality of Life in Families Raising Children with Autism. California: School of Professional Psychology Allinant International University, Doktora Tezi, 2007.

McConnell, Kelly vd. "Examining the Links between Spiritual Struggles and Symptoms of Psychopathology in a National Sample". J Clin Psychol 62 (2006), 1469-1484. https://doi.org/10.1002/jclp.20325

Oti-Boadi, Mabel - Asante, Kwaku O. "Psychological Health and Religious Coping of Ghanaian Women with Infertility". Bio Psycho Medicine 11/20 (2017), 1-7. https://doi.org/10.1186/s13030-017-0105-9 
Özcan, Zeynep. "Mülteci Öğrencilerin Kültürel Uyumları ile Dini Başa Çıkmaları Arasındaki İliş̧i Üzerine Bir Araştırma". Cumhuriyet İlahiyat Dergisi 23/1 (2019), 127-147. https://doi.org/10.18505/cuid.510680

Pargament, Kenneth I. vd. "The Many Methods of Religious Coping: Development and Initial Validation of the RCOPE". Journal of Clinical Psychology 56 (2000), 519-543. https://doi.org/10.1002/(sici)1097-4679(200004)56:4\%3C519::aidjclp6\%3E3.0.co;2-1

Pearce, Michelle J. Religious Coping and Belief Systems Associated with the Well-Being and Experience of Caregivers of Terminally Ill Patients. Connecticut: Yale University, Doctor of Philosophy, Doktora Tezi, 2007.

Post, Brian C. Religious and Spiritual Issues in Group Counseling: Beliefs and Preferences of University Counseling Center Clients and Therapists. Iowa: Iowa State University, Counseling Psychology, Doktora Tezi, 2012.

Rand, Kevin L. vd. "Illness Appraisal, Religious Coping and Psychological Responses in Men with Advanced Cancer". Support Care Cancer 20 (2012), 1719-1728. https://doi.org/10.1007/s00520-011-1265-y

Rosmarin, David vd. "Integrating Spirituality in to Cognitive Behavioral Therapy in an Acute Psychiatric Setting: A Pilot Study". Journal of Cognitive Psychotherapy: A International Quarterly 25/4 (2011), 287-303. https://doi.org/10.1891/2F0889-8391.25.4.287

Rosmarin, David vd. "Religion as a Predictor of Psychological Distress in Two Religious Communities". Cognitive Behaviour Therapy 38/1 (2009), 54-64. https://doi.org/10.1080/16506070802477222

Rosmarin, David vd. "The Role of Religiousness in Anxiety, Depression and Happiness in a Jewish Community Sample: A Preliminary Investigation". Mental Health, Religion \& Culture 12/2 (2009), 97-113. https://doi:10.1080/13674670802321933.

Sankhe, Amit vd. "Spiritual Care Therapy on Quality of Life in Cancer Patients and Their Caregivers: A Prospective Non-Randomized Single-Cohort Study". J Relig Health 56 (2017), 725-731. https://doi.org/10.1007/s10943-016-0324-6

Sarıhan, Cemile Ö. Engelli Çocuğa Sahip Olan ve Olmayan Annelerin Aile İşlevlerini Algılamaları ile Yalnızlık Düzeylerinin İncelenmesi. Ankara: Ankara Üniversitesi, Fen Bilimleri Enstitüsü, Yüksek Lisans Tezi, 2007.

Schreiber, Judy A. "Image of God: Effect on Coping and Psychospiritual Outcomes in Early Breast Cancer Survivors". Oncology Nursing Forum 38/3 (2011), 293-301. https://doi.org 10.1188/11.0NF.293-301

Seyhan, Beyazıd Y. "Üniversite Öğrencilerinde Tanrı Tasavvuru ve Psikolojik İyi Olma Hali Arasındaki İlişkiler". Cumhuriyet Üniversitesi İlahiyat Fakültesi Dergisi 18/1 (2014), 65-97. https://doi.org/10.18505/cuifd.254637

Smith, Tom E. C. vd. Families and Children with Special Needs. New Jersey: Pearson, 2006.

Softa, Havva Kaçan. "Engelli Çocuğa Sahip Ebeveynlerin Depresyon Düzeylerinin İncelenmesi”. Kastamonu Eğitim Dergisi 21/2 (2013), 589-600.

Sun, Virginia vd. "Palliative Care and Spiritual Well-Being in Lung Cancer Patients and Family Caregivers". Psycho-Oncology 25 (2016), 1448-1455. http://dx.doi.org/10.1002/pon.3987

Şentepe, Ayşe. Yaşlılık Döneminde Temel Problemler ve Dini Başa Çıkma. İstanbul: Marmara Üniversitesi Sosyal Bilimler Enstitüsü, Yüksek Lisans Tezi, 2009.

Şirin, Turgay. Bilişsel Davranış̧̧ı Psikoterapi Yaklaşımıyla Bütünleștirilmiş Dini Danışmanlık Modeli. Sakarya: Sakarya Üniversitesi, Sosyal Bilimler Enstitüsü, Doktora Tezi, 2013. 
Taanila, Anja vd. "Coping of Parents with Physically and/or Intellectually Disabled Children". $\begin{array}{lllll}\text { Child, Care, Health \& Development 28/1 (2002), 73-86. } & \end{array}$ https://doi.org/10.1046/j.1365-2214.2002.00244.x

Tarakeshwar, Nalini - Pargament, Kenneth I. "Religious Coping in Families of Children with Autism". Focus on Autism and Other Developmental Disabilities 16/4 (2001), 247-260. https://doi.org/10.1177/2F108835760101600408

Tokur, Behlül. Imtihan Psikolojisi Var Olmanın Hakkını Vermek: Imtihan. Ankara: Fecr Yayınları, 2018.

Uysal, Veysel vd. "Dini Başa Çıkma ile Umut, Hayat Memnuniyeti ve Psikolojik Sağlamlık Arasındaki Etkileşim Üzerine Bir Araştırma". Marmara Üniversitesi İlahiyat Fakültesi Dergisi 52 (2017), 139-160. https://doi.org/10.15370/maruifd.333535

Veisson, Marika. "Depression Symptoms and Emotional States in Parents of Disabled and NonDisabled Children". Social Behavior and Personality: An International Journal 27/1 (1999), 87-98. https://doi.org/10.2224/sbp.1999.27.1.87

William Breitbart vd. "Meaning-Centered Group Psychotherapy for Patients with Advanced Cancer: A Pilot Randomized Controlled Trial". Psycho-Oncology 19/1 (2010), 21-28. https://doi.org/10.1002/pon.1556

Wing, Lorna. Otizm El Rehberi. İstanbul: Doğan Kitap, 2005. 